\title{
Kardiometabolikus betegségek megelőzése és gyógyítása jógával
}

\author{
Apor Péter dr. ${ }^{1,2}$ \\ ${ }^{1}$ Sporttudományi Egyetem, Budapest \\ ${ }^{2}$ Országos Sportegészségügyi Intézet, Budapest
}

\begin{abstract}
A jóga növekvő népszerúsége indokolja a használhatóságról szóló tájékoztatást. Az összefoglaló tanulmányban az ősi megelőző-gyógyító célú jóga alkalmazásáról szóló közleményeket tekinti át a szerző. Egyértelműen alkalmazható a jóga teljessége a kardiometabolikus kockázati tényezők mérséklésére. Az étkezés és a psziché rendezésével, valamint a légző- és tartási gyakorlatok összességével elérhető a fizikai aktivitás javítása. A gyógyszeres és egyéb kezelések jógával történő kiegészítésének nincs ellenjavallata avatott jógainstruktor irányítása mellett. Hátrányos mellékhatást csak helytelen alkalmazáskor észleltek. Előnye az alacsony költség és a széles körben alkalmazhatóság, hátránya a jógaiskolák és a jógainstruktorok különbözősége. Orv. Hetil., 2016, 157(9), 323-327.
\end{abstract}

Kulcsszavak: kardiometabolikus kockázati tényezők, hypertonia, ritmuszavarok, hatásmechanizmus

\section{Preventive and curative value of yoga in cardiometabolic diseases}

\begin{abstract}
Yoga and other body-mind techniques enjoy an increasing popularity in many fields of health maintaining practices, in prevention of some illnesses and in curative medicine in spite of our incomplete knowledge about its applicability and effects. There are large differences among the various yoga-schools and the heterogeneity of indications etc. In this article a bucket of recent information is offered for the inquirers on the potential advantages of yoga (diet, mindexercises, asanas, pranayamas) for decreasing cardio-metabolic risk factors, stabilizing mental health, and its addictive use in curative medicine. Few adverse side-effects may occur only in the case of misapplication. Its advantages are low costs, availability for broad population, and very few contraindications. Disadvantages include differences in the ability of yoga instructors and in yoga practices.
\end{abstract}

Keywords: cardiometabolic risk, hypertension, heart rhythm abnormalities, mechanisms of action

Apor, P. [Preventive and curative value of yoga in cardiometabolic diseases]. Orv. Hetil., 2016, 157(9), 323-327.

(Beérkezett: 2015. november 19.; elfogadva: 2015. december 31.)

A sok ezer éves jóga, amely az utóbbi évszázadokban leginkább Indiában talált honra, egy évszázada Magyarországon is igen népszerü volt. Egyik hazai orvos apostola, Weninger Antal 14. kötete a jógáról 1939-ben került a közönség elé. Politikai repressziós évtizedek után - miközben Weninger dr. Budapesten a Rákóczi út 62 . ben rendelt hetente háromszor - az újraírt „Az idő partján” című könyvét a Tankönyvkiadó adta közre 1986ban. Ennek bevezetővel, magyarázó jegyzetekkel és ábrasorokkal kiteljesedett 2013-as kiadása az 1999-ben alakult Magyar Jóga Társaság elnöke, Selmeczi Csongor és $d r$. Róbert László közremúködésével jelent meg [1]. Ez a könyv nem foglalkozik az indikációkkal, hanem a jógaelméletet és -technológiát írja le. Az indiai kiadású könyvek $[2,3]$ is a jógapraktizőröknek és az érdeklődők- nek szóló ismertetők, nem pedig tudományos hatáselemzések.

Mivel a Jóga Szövetség szerint hazánkban meredeken nő a jógázók és jógaklubok száma - akárcsak az Amerikai Egyesült Államokban és Kanadában, ahol több tízmilliós a jógázók közössége -, érdemes tájékozódni a jóga hasznáról a korszerú medicina értékelési szabályai szerint. Ezt próbálja segíteni a legutóbbi évek közleményeiből válogatott csokor.

A jóga - mint megelőző/terápiás beavatkozás - irodalma meredeken nő: 1967-2013 között 486 megfelelő nívójú közlemény jelent meg, közülük lektorált lapban 217 cikk, melyek 29 országból 28 ezer jógázóról számolnak be. A publikációk száma az utóbbi tíz év során megháromszorozódott, ezek mintegy fele randomizált, 
kontrollcsoportos vizsgálat. A legtöbb közleményt természetesen Indiából írták, az Amerikai Egyesült Államokból 122-t, Kanadából 13-at. A fó indikációk a mentális egészség, a cardiovascularis és a légzőszervi betegségek voltak [4].

Észak-Amerikában fóleg a hatha jóga a legismertebb, amelyet ászánák (testhelyzetek), légzőgyakorlatok (pranayama, Kriya), meditáció (Sahaj, Dhayana), filozófiai oktatás és a minden jógaeljárásban alapvető életvezetésiétkezési tanácsok jellemeznek. Ezek hasonló mérvű kedvező változásokat idéznek elő, mint a rendszeres futás írja több szerző, akik ilyen csoportokat hasonlítottak össze [5]. A jógázó középkorúak aerob kapacitása magasabb lehet, mint a rendszeres fizikai aktivitást végzőké [6].

\section{Jóga mint preventív eljárás a kardiometabolikus megbetegedések ellen}

A stressz és a depresszió csökkentése mellett kedvező hatásról számoltak be a cardiovascularis kockázati tényezők, mint a hypertonia [7, 8], inzulinrezisztencia [9] és a hyperlipidaemia mérséklésében [10]. Diagnosztizált szívbetegség eseteiben hatásossága nem világos [11].

Cramer és mtsai [12] 44 randomizált, kontrollált vizsgálat összegzéseként, amelyben 3168 nem diabeteses, de nagy kockázatú, valamint cukorbeteg személy adatait egyesítve azt látták, hogy a „szokásos kezelés”-sel vagy semmi intervencióval szemben a jógázókon található változások a következők: a szisztolés vérnyomás $-5,85$, a diasztolés -4,12 Hgmm, a pulzusszám -6,59/perc, a légzésszám -0,93/perc, a haskörfogat $-1,95 \mathrm{~cm}$, az összkoleszterin -13,09 mg/dl, a VLDL -5,70 mg/dl, a triglicerid $-20,97 \mathrm{mg} / \mathrm{dl}$, a $\mathrm{HbA}_{\mathrm{lc}}-0,45 \%$, az inzulinrezisztencia $-0,19$ csökkenést mutatott, míg a HDL-koleszterin $+2,94 \mathrm{mg} / \mathrm{dl}$-rel nőtt. Az edzéssel szemben a jóga a HDL-t nagyobb mértékben növeli. Klinikailag jelentős a javulás minden cardiovascularis kockázati tényezőben, ezért a jóga „kiegészítő intervencióra alkalmas mind az általános népességben, mind a nagy kockázatú egyének körében”.

Chu és munkatársainak [13] áttekintése 37 randomizált, kontrollált vizsgálat metaanalízise alapján a következőket mutatta: a nem edzőkkel szemben a jóga a BMI-t $0,77 \mathrm{~kg} / \mathrm{m}^{2}$-rel, a szisztolés vérnyomást $5,21 \mathrm{Hgmm}$ rel, az LDL-koleszterint 12,14 mg/dl-rel csökkentette, a HDL-koleszterint $3,2 \mathrm{mg} / \mathrm{dl}$-rel emelte. A testsúly 2,32 kg-mal, a diasztolés vérnyomás 4,98 Hgmm-rel, az összkoleszterin 15,6 mg/dl-rel, a nyugalmi pulzus 5,27 ütés/perccel csökkent. A vércukor és a glikált hemoglobin csökkenése nem volt szignifikáns. A fizikai edzés és a jóga hatása nem különbözött a kockázati tényezők mérséklése tekintetében.

A szívfrekvencia-variabilitás a 12 hetes jógaedzés során még nagyobb mértékben javult, mint úszóedzést végzőkön [14].
Egy vizsgálatban 20-60 éves, dekádonkénti csoportok napi 1 óra jógagyakorlást végeztek 3 hónapig. A vérnyomás, a szívstressz jelentősen csökkent, a szívfrekvenciavariabilitás a szimpatikus tónus csökkenését mutatta, a katecholamin, adrenokortikotrop hormon és a kortizol szintje csökkent, a szerotonin, dopamin és a brain-derived neurotrop faktor nőtt [15].

A közlések gyenge minősége azonban zavaró. Kevés a random, kontrollcsoportos tanulmány. A hatás (például „diasztolés vérnyomás $-2,9 \mathrm{Hgmm}$, triglicerid $-0,27$ mmol/1, HDL +0,08 mmol/1, LDL bizonytalan") klinikailag olykor nem jelentős. Nem jeleztek mellékhatást, költségeket. „Van némi evidencia, hogy hatékony a vérnyomásra, HDL-re és trigliceridre" [16]. A jógabeavatkozások sokfélesége, tartama, gyakorisága nem azonos: négy, Indiából származó randomizált, kontrollált tanulmány a coronariabetegek jógakezeléséról sokféle diagnosztikus kritériumot, jógagyakorlatot, a gyakorlatvezetők képzettségének sokféleségét, nem adekvát randomizációt, hiányos mortalitási-morbiditási adatokat tartalmazott.

A jóga csökkenti az elhízással járó gyulladási faktorokat szívbetegeken - ezekről például Sarvottam és Yadav [17] adtak áttekintést. Diabetesben is hatásos lehet a jóga: a hagyományos aerob edzés mellett a rezisztencia-, egyensúly-, nyúlékonyságedzések, valamint a jóga és tajcsi is javítja a cukorbetegek állapotát [18]. Kínai metabolikus szindrómások egyéves jógaintervenciója a haskörfogatot és a vérnyomást jelentősen csökkentette a kontrollokéhoz képest, ezért komplementer kezelésként javasolják [19].

Általános vélemény szerint a jóga csökkenti a vérnyomást [7, 20-24]. A stressz és a vérnyomás csökkenése a leggyakrabban említett jógahatás. Az egyes jógagyakorlatok nem egyformán hatnak a pulzusra és vérnyomásra egészségeseken [25]. Posadzki és mtsai [26] 17 megfelelő randomizált, kontrollált tanulmányt találtak: 11 szerint a jóga nagyobb vérnyomáscsökkenést okozott, mint a farmakoterápia. Ötben nem volt jobb a hatása, mint az étkezésjavításnak, 8-ban az étkezés nem csökkentette a diasztolés vérnyomást a farmakoterápia és a mozgás hatásához képest.

Három hónapig 26 alkalommal végzett jógagyakorlás során a negatív affektus, szorongás és depresszió, a relaxációs állapotot jelző skálaértékek javultak és a vérnyomás is javult [27].

Cramer és mtsai Essenből a hypertonia és a jóga összefüggéseivel kapcsolatos metaanalízisükben [28] a legalább 8 hetes jóga hatását vizsgálták. Megállapításuk szerint az egyébként igen alacsony minőségü vizsgálatok nagy heterogenitást mutattak. Az elemzésbe bevont vizsgálatokban 452 betegnél a jóga 9,6 Hgmm szisztolés és 7,2 Hgmm-es diasztolésvérnyomás-csökkenést váltott ki, ami nem múlta felül a fizikai aktivitás hatását. Wang és mtsai [29] 6 randomizált, kontrollált tanulmányban részt vevő 386 beteg adatainak analízise alapján biztatónak ítélték a jóga hatását a vérnyomáscsökkentésre, de a tanulmányok minősége gyenge volt. Három hónapos 
jóga 60-80 éves hypertoniás betegekben csökkentette a malon-dialdehid-szintet, növelte a S-glutationt és a szuperoxid dizmutázt, vagyis javította az oxidatív stressz elleni védelmet [23].

A jóga és hypertonia témában 6693 személy részvételéről készült szisztémás áttekintés szerint heterogének a jógapraktikák, igen változékonyak a hatások, így nehéz kijelölni valamelyik gyakorlatot hatásosnak [30]. A svéd Kundalini-jógát használták 28 metabolikus szindrómás, hypertoniás, gyógyszert szedő betegen heti 60 perc felügyelt és otthoni minden nap 30 perces jógagyakorlással a „szokásos kezeléssel” szemben. Bár a szerzők korábbi tanulmányában a Kundalini-jóga vérnyomáscsökkenést váltott ki, ebben a vizsgálatban változott a vérnyomás és a vérparaméterek változatlanok maradtak, amit a szerzők a maximális vérnyomáscsökkentő gyógyszereléssel magyaráztak [31].

Mindezek alapján azt mondhatjuk, hogy a jóga és/ vagy meditáció mérsékli a cardiovascularis kockázati tényezőket, a hypertoniát, diabetest, inzulinrezisztenciát, dyslipidaemiát és fékezheti a coronariabetegség progresszióját. Friss tanulmányok szerint a transzcendentális meditáció $48 \%$-kal csökkentette a cardiovascularis eseményeket 5 éves megfigyelés alatt, és alkalmas lehet a pitvarfibrilláció megelőzésére. A tanulmányok gyenge minősége miatt azonban csak óvatosan állítható, hogy kis költsége és a mellékhatások csekély súlya miatt a jóga beépíthető a primer vagy szekunder prevencióba [32].

\section{Jóga a szívbetegek számára}

Coronariabypass után 6 héttel, 6 hónappal és 12 hónappal 1026 betegen (életkor: 35-65 év) értékelték a csak fizioterápia és a fizioterápia + jóga hatását. A fizioterápia gimnasztikai jellegű volt, a mindennapi feladatok gyakorlásával, ízületiterjedelem-növeléssel és légzőgyakorlatokkal. A jógacsoportban egy év alatt jobban nőtt az 53\% alatti ejekciós frakciójú betegek kamramúködése, a testtömegindex nagyobb mértékben csökkent, a vércukor, HDL-koleszterin és VLDL-koleszterin nagyobb mértékben javult, a pozitív affektus jobban nőtt, nagyobb mértékben csökkent a megélt stressz, a szorongás, a depreszszió és a negatív affektus, míg a másik csoportban csak a szorongás csökkent [33]. 30 jóga- és 29 konvencionális kezelésben részesülő, szívelégtelenségben szenvedő beteget magába foglaló metaanalízis szerint a jóga növelte a $\mathrm{VO}_{2 \max }$-ot és javította az életminőséget, ezért a brazil szerzők a jóga bevonását javasolták a szívbetegek rehabilitációs programjába [34]. Egy másik vizsgálatban szisztolés és diasztolés szívelégtelenségben szenvedó afroamerikai betegek az otthoni gyaloglásprogramhoz csatlakozva jógában is részesültek. A jógázók jobb eredményt értek el hajlékonyságban, futószalagidőben, $\mathrm{VO}_{2 \max }$-értékben, interleukin-6-szintben, C-reaktív protein-szint-csökkenésben és extracelluláris szuperoxid dizmutáz szintben, mint a nem jógázók [35].
Cramer és mtsai [36] fenntartásokat fogalmaztak meg a coronariabetegség, a szívelégtelenség és a szívritmuszavarok jógakezeléséról szóló közleményekkel kapcsolatban. Véleményük szerint csak gyenge érvek szólnak a jóga alkalmazásának hasznáról a szívbetegeken. Hátrányos mellékhatásokat, halálozási adatokat általában nem említenek ezek a források.

A különböző szívritmuszavarokban a jógát hatásosnak találták és az eredményeket nagy szimpóziumokon is tárgyalták [37]. Megállapították, hogy a BKD lyengar jóga a pitvarfibrillációt nem gyógyítja, de csökkenti a tüneteket, feltehetően a szimpatikus tónus csökkentése és a paraszimpatikus hatás növelése révén. Más szerzők [38] a kamrai repolarizáció szóródásának csökkenését észlelték jógalégzés hatására, míg Lakkireddy és mtsai [39] a pitvarfibrillációs epizódok ritkulását, a szorongás oldódását látták. A gyógyszeres és ablatiós kezelés mellett a jóga, az akupunktúra és a bio-feed-back is csökkenti a pitvarfibrillációs epizódok számát. Az ómega-3 zsírsavak, antioxidánsok, barberry, motherwort, cinchoma, Shensongyangxin, hawthorn, Kella és Wenxin Keli is bírhat valamennyi terápiás jelentőséggel, de hasznuk igazolásához megfelelő tanulmányok szükségesek [40].

Brenyo és Aktas 624 beteget magába foglaló, 7 randomizált, kontrollált tanulmány alapján a komplementer és alternatív kezelést a depresszió és stressz csökkentésében és az életvezetés javításában találták hatékonynak [41].

A neurokardiogén syncope adjuváns kezelése során a jóga hatására (heti háromszor 3 hónapig) az epizódok száma csökkent, a praesyncope ritkult, a syncopestátusz kérdőíves pontszáma 67-ről 29,8\%-ra és az asztaldöntési teszt a korábbi összes pozitívról 28\%-ra csökkent [42].

\section{Légzésfunkció, tüdőbetegségek}

Egészséges fiataloknál a 12 hetes lassú és gyors pranayama gyakorlás a légzésfunkciós mutatók nagy részét javította, a gyors gyakorlatok hatása nagyobb volt [43].

Coronariabetegek 3 hónapos légző- és testtartásedzése, diétás tanács és holisztikus tanítás növelte a lassú és eróltetett vitálkapacitást, kilégzési csúcsáramlást, maximális akaratlagos légzést és CO-transzfer-faktort a szokásos kezelésben részesült kontrollokhoz képest [44].

Egy esettanulmány szerint pulmonalis hypertoniában a jóga nem okozott mellékhatást, csökkentette a szorongást és az ízületi fájdalmat, valamint javította a Health Promoting Lifestyle Profile II kérdőív és a 6 perces gyaloglási teszt eredményeit [45]. Az asztmás betegek számára a jógázás rutinszerűen nem javasolt [46].

A jóga szakirodalma bőségesen tárgyalja a szóba jövő hatásmechanizmusokat, amelyek közül néhány friss „nyugati” közlemény külön figyelmet érdemel. A lassú légzés egyik szerepét abban látják, hogy mérsékli a betegség nyomán kialakult depressziót és szorongást, a mentális egészség előmozdítása pedig javítja a cardiovascularis rendszer állapotát. Felvetődött, hogy lassú légzés alatt az orrmelléküregekben megnövekvő nitrogén-mo- 
noxid felszívódása fejti ki a hatást. Paprika és mtsai [47] a 6/perc légzésszám megtartásával a be-ki légzés időarányt 3:7-7:3 közötti tartományban változtatva azt találták, hogy az autonóm reakciókra leginkább a légzésgyakoriság hat és nem a légzésciklus változása.

Lassú légzés alatt (a jógában szokásos 6/perc légzésszám) a funkcionális mágneses rezonanciás vizsgálattal az agyban a hátsó híd, aqueductus körüli szürkeállomány, cerebellum, hypothalamus, thalamus, valamint a lateralis és anterior insularis kéreg egyes területeinek aktiválódását mutatták ki. Az agyi magvak részt vesznek a pulzuskontrollban is [48].

A Surya Namaskar jóga 12 fizikai pozíciót jelent előrehátra hajlással és közben légzéssel. Egy vizsgálatban ezeket a gyakorlatokat 9 egészséges katona végezte napi 1 órán keresztül 11 hónapon át. A gyakorlás közben a $\mathrm{VO}_{2}$ a kezdeti $0,795 \mathrm{l} /$ perc.kg-ról a 11 . hónapra fokozatosan $0,560 \mathrm{l} /$ perc.kg -ra, a pulzusszám 92/percről 87 /percre, a légzésmélység 1,09 literről 0,957 literre csökkent, míg a légzésszám nem változott. Ezek a változások a mozgás aerob hatásfokának javulását, gazdaságosabbá válását jelezték [49].

A „mind-body” praktikák és a cardiovascularis egészség kockázati tényezőiről szól a Rotterdam-tanulmány. A 2579 egészséges személyen, akik valamilyen test-lélek gyakorlásban vettek részt (meditáció, jóga, self-prayer, légzőgyakorlatok vagy egyéb), alacsonyabb testtömegindex-értéket, kisebb éhomi vércukor- és trigliceridszintet, valamint a metabolikus szindróma ritkább előfordulását találták [50]. A jóga energiaigénye kicsi, ezért a kedvezőbb paraméterek a jógát gyakorlók egészségesebb étkezési szokásaival magyarázhatók [51]. A biológiai kockázati tényezőkön túl a pszichoszociális stressz és depresszió csökkentésében közremúködhet a jóga, ami a test-lélek kapcsolat tudatossá tételével életvezetésbeli javulásra serkenti a gyakorlóit. Feltételezik, hogy a jóga és a pranayama nagyon jó megelőzési módszer a nyugati és keleti orvoslásban egyaránt [52].

A jóga káros mellékhatásairól általában nem esik szó. Cramer és mtsai egy szisztémás áttekintésben [53] elemezték a közölt mellékhatásokat és mindössze 76 publikált esetet találtak. Glaucoma, osteopenia, izom-, ízületés csontrendellenességek esetén a testtartások, fejen állás, lótuszpozíció és az erőltetett légzési manőverek oktatása nagy figyelmet kíván, illetve kerülendő.

\section{Következtések}

A sokféle jógairányzat és -gyakorlat közül a Hatha, a Lyengar a legismertebb a nyugati világban. Kedvező a hatásuk a cardiovascularis és metabolikus kockázati tényezőkre, a pszichés állapotra, a diétás előírásokkal és életvezetés-korrekcióval együtt. A fizikai aktivitás programokhoz képest a jóga kisebb energiaigényt jelent, a kedvező hatás inkább a vegetatív idegrendszer kedvező áthangolásán át jut érvényre (a diéta és életvitel-korrekció közösségén túl). Nincs adat, amely ellentmondana a jóga és a fizikai edzés együttes alkalmazásának. A kellő intenzitású és tartamú fizikai aktivitást (mérsékelt-közepes intenzitású, heti 5 alkalommal 30-60 perces, tünetmentesség esetén nagyobb intenzitású, de heti legalább 150 perces, akár „high-intensity interval” mozgások és heti legalább két rezisztenciaedzés a metabolikusan aktív izomtömeg és az erő megtartására) jól egészítheti ki a mentális egészség és a vegetatív idegrendszer ápolását célzó, a légzőrendszert is fejlesztő jógázás.

Anyagi támogatás: A közlemény megírása anyagi támogatásban nem részesült.

A szerző a cikk végleges változatát elolvasta és jóváhagyta.

Érdekeltségek: A szerzőnek nincsenek érdekeltségei.

\section{Irodalom}

[1] Weninger, A.: In the border of time. Yoga and personality. [Az idő partján. Jóga és személyiség.] SpringMed Kiadó, Budapest, 2013. [Hungarian]

[2] Saraswati, Swami Satyananda: Yoga and cardiovascular management. Yoga Publications Trust, Munger, Bihar, 2001.

[3] Shankardevananda, Swami: Yoga on hypertension. Bihar School of Yoga, Munger, Bihar, 1998.

[4] Jeter, P. E., Slutsky, J., Singh, N., et al.: Yoga as a therapeutic intervention: A bibliometric analysis of published research studies from 1967 to 2013. J. Altern. Complement. Med., 2015 21(10), 586-592.

[5] Satin, J. R., Linden, W., Millman, R. D.: Yoga and psychophysiological determinants of cardiovascular health: comparing yoga practitioners, runners, and sedentary individuals. Ann. Behav. Med., 2014, 47(2), 231-241.

[6] Sovová, E., Cajka, V., Pastucha, D., et al.: Positive effect of yoga on cardiorespiratory fitness: A pilot study. Int. J. Yoga, 2015, $8(2), 134-138$

[7] Hagins, M., States, R., Selfe, T., et al.: Effectiveness of yoga for hypertension: systematic review and meta-analysis. Evid. Based Complement. Alternat. Med., 2013, 2013, 649836.

[8] Hagins, M., Rundle, A., Consedine, N. S., et al.: A randomized controlled trial comparing the effects of yoga with an active control on ambulatory blood pressure in individuals with prehypertension and stage 1 hypertension. J. Clin. Hypertens., 2014, 16(1), 54-62.

[9] Innes, K. E., Bourguignon, C., Taylor, A. G.: Risk indices associated with the insulin resistance syndrome: cardiovascular disease, and possible protection with yoga: a systematic review. J. Am. Board Fam. Pract., 2005, 18(6), 491-519.

[10] Yang, K.: A review of yoga programs for four leading risk factors of chronic diseases. Evid. Based Complement. Alternat. Med., 2007, 4(4), 487-491.

[11] Lau, H. L., Kwong, J. S., Yeung, F, et al.: Yoga for secondary prevention of coronary disease. Cochrane Database Syst. Rev., 2012, (12), CD009506.

[12] Cramer, H., Lauche, R., Haller, H., et al.: Effect of yoga on cardiovascular disease risk factors: a systematic review and metaanalysis. Int. J. Cardiol., 2014, 173(2), 170-183.

[13] Chu, P., Gotink, R. A., Yeh, G. Y., et al.: The effectiveness of yoga in modifying risk factors for cardiovascular disease and metabolic syndrome: A systematic review and meta-analysis of randomized controlled trials. Eur. J. Prev. Cardiol., 2016, 23(3), 291-307. 
[14] Sawane, M. V., Gupta, S. S: Resting heart rate variability after yogic training and swimming: A prospective randomized comparative trial. Int. J. Yoga, 2015, 8(2), 96-102.

[15] Pal, R., Singh, S. N., Chatterjee, A., et al.: Age-related changes in cardiovascular system, automic functions, and levels of BDNF on healthy active males: role of yogic practice. Age, 2014, 36(4), 9683

[16] Hartley, L., Dyakova, M., Holmes, J., et al.: Yoga for the primary prevention of cardiovascular disease. Cochrane Database Syst. Rev., 2014, (5), CD010072.

[17] Sarvottam, K., Yadav, R. K.: Obesity-related inflammation \& cardiovascular disease: efficacy of a yoga-based lifestyle intervention. Indian J. Med. Res., 2014, 139(6), 822-834.

[18] Armstrong, M. J., Colberg, S. R., Sigal, R. J.: Moving beyond cardio: the value of resistance training, balance training, and other forms of exercise in the management of diabetes. Diabetes Spectr., 2015, 28(1), 14-23.

[19] Siu, P. M., Yu, A. P., Benzie, I. F., et al.: Effects of 1-year yoga on cardiovascular risk factors in middle-aged and older adults with metabolic syndrome: a randomized trial. Diabetol. Metab. Syndr., $2015,7,40$

[20] Ziv, A., Vogel, O., Keret, D., et al.: Comprehensive Approach to Lower Blood Pressure (CALM_BP): a randomized controlled trial of multifactorial lifestyle intervention. J. Hum. Hypertens. 2013, 27(10), 594-600.

[21] Mizuno, J., Monteiro, H. L.: An assessment of a sequence of yoga exercises to patients with arterial hypertension. J. Bodyw. Mov. Ther., 2013, 17(1), 35-41.

[22] Thiyagarajan, R., Pal, P., Pal, G. K., et al.: Additional benefit of yoga to standard lifestyle modification on blood pressure in prehypertensive subjects: a randomized controlled study. Hypertens. Res., 2015, 38(1), 48-55

[23] Patil, S. G., Dhanakshirur, G. B., Aithala, M. R., et al.: Effect of yoga on oxidative stress in elderly with grade-I hypertension: a randomized controlled study. J. Clin. Diagn. Res., 2014, 8(7), BC04-BC07.

[24] Cohen, D. L., Bloedon, L. T., Rothman, R. L., et al.: Iyengar Yoga versus enhanced usual care on blood pressure in patients with prehypertension to stage I hypertension: a randomized controlled trial. Evid. Based Complement. Alternat. Med., 2011, $2011,546428$.

[25] Bhavanani, A. B., Ramanathan, M., Balaji, R., et al.: Comparative immediate effect of different yoga asanas on heart rate and blood pressure in healthy young volunteers. Int. J. Yoga, 2014, $7(2), 89-95$.

[26] Posadzki, P., Cramer, H., Kuzdzal, A., et al.: Yoga for hypertension: a systematic review and randomized clinical trials. Complement. Ther. Med., 2014, 22(3), 511-522.

[27] Tolbaños Roche, L., Mas Hesse, B.: Application of an integrative yoga therapy programme in cases of essential arterial hypertension in public healthcare. Complement. Ther. Clin. Pract., 2014 20(4), 285-290.

[28] Cramer, H., Haller, H., Lauche, R., et al.: A systemic review and meta-analysis of yoga for hypertension. Am. J. Hypertens., 2014, 27(9), 1146-1151

[29] Wang, J., Xiong, X., Liu, W.: Yoga for essential hypertension: a systematic review. PLoS ONE, 2013, $8(10)$, e76357.

[30] Tyagi, A., Cohen, M.: Yoga and hypertension: a systemic review. Altern. Ther. Health Med., 2014, 20(2), 32-59.

[31] Wolff, M., Memon, A. A., Chalmers, J. P., et al.: Yoga's effect on inflammatory biomarkers and metabolic risk factors in a high risk population - a controlled trial in primary care. BMC Cardiovasc. Disord., 2015, 15, 91.

[32] Manchanda, S. W.: Yoga - a promising technique to control cardiovascular disease. Indian Heart J., 2014, 66(5), 487-489.

[33] Raghuram, N., Parachuri, V. R., Swarnagowri, M. V., et al.: Yoga based cardiac rehabilitation after coronary artery bypass surgery: One-year results on LVEF, lipid profile and psychological states -
A randomized controlled study. Indian Heart J., 2014, 66(5), 490-502.

[34] Gomes-Neto, M., Rodrigues, E. S. Jr., Silva, W. M. Jr., et al.: Effects of yoga in patients with chronic heart failure: A meta-analysis. Arq. Bras. Cardiol., 2014, 103(5), 433-439.

[35] Pullen, P. R., Thompson, W. R., Benardot, D., et al.: Benefits of yoga for African American heart failure patients. Med. Sci. Sports Exerc., 2010, 42(4), 651-657.

[36] Cramer, H., Lauche, R., Haller, H., et al.: A systematic review of yoga for heart disease. Eur. J. Prev. Cardiol., 2015, 22(3), 284295.

[37] Lakkireddy, D.: Role of yoga and stress reduction techniques in the management of AF. Boston Atrial Fibrillation Symposium, 2012, January 12-14.

[38] Dabhade, A. M., Pawar, B. H., Ghunage, M. S., et al.: Effect of pranayama (breathing exercise) on arrhythmias in the human heart. Explore (N.Y.), 2012, 8(1), 12-15.

[39] Lakkireddy, D., Atkins, D., Pillarisetti, J., et al.: Effect of yoga on arrhythmia burden, anxiety, depression, and quality of life in paroxysmal atrial fibrillation: the YOGA My Heart Study. J. Am. Coll. Cardiol., 2013, 61(11), 1177-1182.

[40] Kanmanthareddy, A., Reddy, M., Ponnaganti, G., et al.: Alternative medicine in atrial fibrillation treatment - Yoga, acupuncture, biofeedback and more. J. Thorac. Dis., 2015, 7(2), 185-192.

[41] Brenyo, A., Aktas, M. K.: Review of complementary and alternative medical treatment of arrhythmias. Am. J. Cardiol., 2014, $113(5), 897-903$

[42] Gunda, S., Kanmanthareddy, A., Atkins, D., et al.: Role of yoga as an adjunctive therapy in patients with neurocardiogenic syncope: a pilot study. J. Interv. Card. Electrophysiol., 2015, 43(2), 105-110.

[43] Dinesh, T., Gaur, G., Sharma, V., et al.: Comparative effects of 12 weeks of slow and fast pranayama training on pulmonary function is young, healthy volunteers: a randomized controlled trial. Int. J. Yoga, 2015, 8(1), 22-26.

[44] Yadav, A., Singh, S., Singh, K., et al.: Effect of yoga regimen on lung functions including diffusion capacity in coronary artery disease patients: a randomized controlled study. Int. J. Yoga, $2015,8(1), 62-67$.

[45] Awdish, R., Small, B., Cajigas, H.: Development of a modified yoga program for pulmonary hypertension: a case series. Altern. Ther. Health Med., 2015, 21(2), 48-52.

[46] Cramer, H., Posadzki, P., Dobos, G., et al.: Yoga for asthma: a systematic review and meta-analysis. Ann. Allergy Asthma Immunol., 2014, 112(6), 503-510.e5.

[47] Paprika, D., Gingl, Z., Rudas, L., et al.: Haemodynamic effect of slow breathing. Acta Physiol. Hung., 2014, 101(3), 273-281.

[48] Critchley, H. D., Nicotra, A., Chiesa, P. A., et al.: Slow breathing and hypoxic challenge: cardiorespiratory consequences and their central neural substrates. PloS ONE, 2015, 10(5), e0127082.

[49] Sinba, B., Sinba, T. D.: Effect of 11 months of yoga training on cardiorespiratory responses during the actual practice of Surya Namaskar. Int. J. Yoga, 2014, 7(1), 72-75.

[50] Younge, J. O., Leening, M. J., Tiemeier, H., et al:: Association between mind-body practice and cardiometabolic risk factors: The Rotterdam Study. Psychosom. Med., 2015, 77(7), 775-783.

[51] Ramos-Jiménez, A., Wall-Medrano, A., Corona-Herdández, R. I., et al:: Yoga, bioenergetics and eating behaviour: a conceptual review. Int. J. Yoga, 2015, 8(2), 89-95.

[52] Chaddha, A.: Slow breathing and cardiovascular disease. Int. J. Yoga, 2015, 8(2), 142-143.

[53] Cramer, H., Krucoff, C., Dobos, G.: Adverse events associated with yoga: a systematic review of published case reports and case series. PLoS ONE, 2013, $8(10)$, e75515.

(Apor Péter dr., e-mail: p.apor.md@gmail.com) 